\title{
A Model of Discovery Learning Based - Text Book of Character and Islamic Education : An Accuracy Analysis of Student Book in Elementary School
}

\author{
Fadriati*) \\ Institut Agama Islam Negeri Batusangkar, \\ Sumatera Barat, Indonesia \\ E-mail: fadriati@iainbatusangkar.ac.id
}

\begin{abstract}
This study aims at developing a valid discoverylearning text book for the Islamic Education $(P A I)$ and Character subject delivered at the fifth grade of Primary School based on the results of the accuracy analysis of the existing student books. This is a Research and Development ( $R$ and $D)$ applying the 4-D model proposed by Semmel and Thiagarajan, that is, defining, designing, developing, and disseminating. Data collection techniques used (1) instrument assessment with the format of student book analysis to measure the level of accuracy of the existing textbooks, (2) interviews and observations, conducted to the PAI teachers, and (3) validation sheets. Moreover, the technique of data analysis used inter rater analysis technique, known as the technique of intra class correlation coefficient analysis (Intraclass Correlation Coefficient-ICC). As the result, in terms of level of accuracy, the existing textbooks of Character and Islamic Education at the fifth grade of elementary school is still low. In general, the teachers claim that the existing text books are able to meet some of the basic competencies and indicators. However, the text books need to be refined and clarified the student learning activities, making it more simple for students to learn. On the other hand, the product of discovery learning textbooks on the subjects of Character and Islamic Education at the fifth grade of elementary school are declared valid. This product is refined based on input, making it feasible for the students at the fifth grade of Primary School in learning Character and Islamic Education.
\end{abstract}

Key words: Model, Character and Islamic Education, Accuracy, Discovery Learning

\section{PENDAHULUAN}

Berdasarkan penelitian pendahuluan yang dilakukan terhadap beberapa orang Guru Pendidikan Agama Islam Sekolah Dasar diketahui bahwa Buku Siswa yang menggunakan pendekatan Tematik Integratif sudah tersedia secara lengkap walaupun masih ada beberapa bagian materi ajar yang kurang lengkap dan kurang relevan. Sedangkan untuk bidang studi Pendidikan Agama Islam dan Budi Pekerti pendistribusiannya masih sangat terbatas. Masih banyak sekolah yang belum menerima Buku Siswa dalam bentuk cetak, melainkan masih dalam bentuk soft copy dan itupun didownload oleh guru yang bersangkutan. (Guru PAI SD, wawancara pribadi: 16 Maret 2017). Selain itu materi ajar yang terdapat pada Buku Siswa masih ada yang kurang lengkap dan cenderung dangkal. Bahkan ada yang tidak memiliki argumentasi yang jelas dan tidak memiliki peta konsep. (Guru PAI SD, wawancara pribadi: 16 Maret 2017). Sumber lain mengatakan bahwa dari segi penampilan Buku Siswa kurang menarik serta kurang didukung dengan kata motivasi dan persuasi terhadap siswa. (Guru PAI SD, wawancara pribadi: 16 Maret 2017). 
Keadaan buku ajar yang demikian mempunyai dampak yang besar terhadap kegiatan belajar dan mutu belajar siswa. Kualitas dan kuantitas buku ajar siswa perlu ditingkatkan. Hal ini dilakukan untuk peningkatan mutu belajar. Sedangkan taraf penguasaan belajar ideal dari siswa adalah yang mencapai kompetensi dasar $90 \%$ atau taraf penguasaan kompetensi minimal 75\%-89\% (Depdiknas 2004:36). Taraf kompetensi demikian sukar dicapai, karena proses pembelajaran yang dialami siswa bermutu kurang mengembirakan. Akibatnya daya serap siswa rendah karena mutu kegiatan belajarnya tidak optimal.

Peneliti sebelumnya telah banyak yang merancang buku ajar untuk mata pelajaran PAI dan Budi Pekerti, namun belum ada yang mengembangkan model buku ajar yang didasarkan pada hasil analisis terhadap tingkat akurasi buku ajar yang telah ada. Di antaranya ada jurnal yang ditulis oleh Ngadimun Hd tentang Penyusunan Buku Ajar Berdasarkan Kurikulum 2013, yang berisi tentang langkah-langkah teknis penyusunan buku ajar berdasarkan kurikulum 2013. Jurnal yang ditulis oleh Ida Bagus Putrayasa tentang Kualitas Bahasa Buku Ajar, yaitu hasil analisis terhadap kualitas bahasa buku ajar pada Kurikulum 2013. Beberapa peneliti terdahulu lainnya lebih banyak mengarahkan penelitiannya pada pengembangan bahan ajar dalam bentuk LKS, modul dan hand out. Belum ditemukan peneliti lain yang melakukan penelitian tentang pengembangan model buku ajar dengan berbasis discovery learning terutama pada bidang studi PAI dan Budi Pekerti.

Tulisan ini bertujuan untuk memaparkan hasil penelitian tentang model buku ajar berbasis discovery learning pada Pendidikan Agama Islam dan Budi Pekerti Sekolah Dasar. Model yang dihasilkan didasarkan atas hasil analisis terhadap akurasi buku siswa yang dikeluarkan oleh Pemerintah untuk mendukung pelaksanaan Kurikulum Nasional tahun 2013.

\section{KAJIAN TEORI}

Buku Ajar Berbasis Discovery Learning

Buku ajar adalah buku pegangan untuk suatu mata ajar yang ditulis dan disusun oleh pakar bidang terkait dan memenuhi kaidah buku teks serta diterbitkan secara resmi dan disebarluaskan (Kep. Mendiknas No.36/D/O/2001, Pasal 5 Ayat 9). Buku ajar berbeda dengan buku teks, karena buku ajar disusun berdasarkan ketentuan-ketentuan khusus yang terkait dengan pembelajaran siswa. Buku ajar disusun untuk memenuhi kebutuhan siswa, agar sesuai dengan ciri karakteristik siswa dan berdasarkan rencana kegiatan belajar siswa.

Buku ajar berisi bahan atau materi ajar yang disusun secara sistematis dan dapat digunakan oleh guru dan siswa dalam proses pembelajaran. Buku ajar mempunyai struktur dan urutan yang sistematis, menjelaskan kompetensi dasar dan indikator pencapaian kompetensi pada masing-masing materi ajar, mampu memotivasi siswa untuk belajar, mengantisipasi kesukaran belajar dalam bentuk bimbingan bagi siswa untuk mempelajari bahan tersebut. Setelah penyajian materi dilanjutkan dengan pemberian latihan, menyediakan rangkuman dan secara umum berorientasi kepada siswa secara individual, bersifat mandiri, sistematis dan lengkap. (Ngadimun: 2013)

Buku ajar untuk setiap bidang studi dapat dibagi menjadi beberapa bagian atau bab. Setiap bab merupakan unit terkecil dari materi ajar yang memuat konsep secara utuh, sehingga dapat dipelajari secara terpisah dari bagian lain tanpa mengurangi maknanya. Batasan pasti tentang jumlah bab buku ajar suatu mata kuliah belum pernah ada, namun perlu diingat bahwa pembagian bab diisi dengan jumlah sub bab. Jumlah halaman buku ajar disesuaikan dengan jumlah Kompetensi Dasar dan Indikator Pencapaian Kompetensi pada setiap bidang studi. 
Kedudukan dan fungsi buku ajar adalah dapat dipergunakan sebagai panduan bagi aktifitas pembelajaran serta memudahkan siswa dalam menguasai materi ajar tertentu. Buku ajar juga digunakan sebagai panduan dalam melaksanakan kegiatan tertentu dalam pembelajaran (activities based learning) di mana isinya dirancang dan dapat dilengkapi dengan contoh-contoh lembar kegiatan agar siswa dapat melakukan pengatamatan dan berbagai aktifitas penunjang untuk kegiatan pembelajaran. Buku ajar juga berfungsi untuk mengaktifkan siswa dalam pembelajaran melalui kegiatan mengamati, menanya, mencoba, menalar, berdiskusi serta meningkatkan kemampuan berkomunikasi dengan baik antar teman dan dengan gurunya. Guru dapat memperkaya materi dan kegiatan lainnya sesuai dengan tujuan pembelajaran yang ditetapkan.

$\begin{array}{ccc}\text { Discovery learning merupakan } & \text { learan } \\ \text { pembelajaran berdasarkan } & \text { penemuan }\end{array}$
(Inquiry based), konstruktivis dan teori bagaimana belajar. Model pembelajaran yang diberikan kepada siswa memiliki skenario pembelajaran untuk memecahkan masalah yang nyata dan mendorong mereka untuk memecahkan masalah mereka sendiri. Dalam memecahkan masalah mereka; karena ini bersifat konstruktivis, para siswa menggunakan pengalaman mereka terdahulu dalam memecahkan masalah. Kegiatan mereka lakukan dengan berinteraksi untuk menggali, mempertanyakan selama bereksperimen dengan teknik trial and error. (Bruner http://www.lifecirclesinc.com)

Model pembelajaran discovery learning menurut Alma dkk (2010:59) juga disebut sebagai pendekatan inkuiri bertitik tolak pada suatu keyakinan dalam rangka perkembangan murid secara independen. Pendekatan inkuiri menekankan kepada pengembangan aspek kognitif, afektif, dan psikomotor secara seimbang, sehingga pembelajaran melalui strategi ini lebih bermakna dan memberikan ruang kepada siswa untuk belajar yang sesuai dengan gaya belajar mereka. (Fadriati: 2014)

Model ini membutuhkan partisipasi aktif dalam penyelidikan secara ilmiah. Hal ini sejalan juga dengan pendapat yang menyatakan bahwa anak harus berperan aktif dalam belajar di kelas seperti yang terdapat pada kutipan berikut. "Discovery learning can be defined as the learning that takes place whenthe student is not presented with subject matter in the final form, but rather is required toorganize it himself' (Lefancois dalam Emetembun, 1986:103 dalam Depdikbud 2014).

Discovery adalah proses pembelajaran yang menitikberatkan pada mental intelektual para anak didik dalam memecahkan berbagai persoalan yang dihadapi, sehingga menemukan suatu konsep atau generalisasi yang dapat diterapkan di lapangan". (Hamalik dalam Ilahi, Jurnal Pena Ilmiah: Vol. 1, No. 1 2016)) Penemuan (discovery) merupakan suatu model pembelajaran yang dikembangkan berdasarkan pandangan konstruktivisme. Kurniasih \& Sani (2014: 64) mendefinisikan discovery learning sebagai proses pembelajaran yang terjadi bila materi pembelajaran tidak disajikan dalam bentuk finalnya, tetapi diharapkan siswa mengorganisasi sendiri.

\section{Dengan demikian Discovery} learning adalah proses belajar yang $\mathrm{di}$ dalamnya tidak disajikan suatu konsep dalam bentuk jadi (final), tetapi siswa dituntut untuk mengorganisasi sendiri cara belajarnya dalam menemukan konsep. Discovery learning mempunyai prinsip yang sama dengan inquiry. Tidak ada perbedaan yang prinsipil pada kedua istilah ini, pada discovery learning lebih menekankan pada ditemukannya konsep atau prinsip yang sebelumnya tidak diketahui. Perbedaannya dengan discovery ialah bahwa pada discovery masalah yang dihadapkan kepada siswa semacam 
masalah yang direkayasa oleh guru, sedangkan pada inkuiri masalahnya bukan hasil rekayasa, sehingga siswa harus mengerahkan seluruh pikiran dan keterampilannya untuk mendapatkan temuan-temuan di dalam masalah itu melalui proses penelitian.

Pengaplikasian model discovery learning dalam mengembangkan cara belajar siswa aktif adalah dengan menemukan sendiri, menyelidiki sendiri, maka hasil yang diperoleh akan tahan lama dalam ingatan. Posisi guru di kelas adalah sebagai pembimbing dan mengarahkan kegiatan pembelajaran sesuai dengan tujuan. Kondisi seperti ini tujuannya adalah ingin merubah kegiatan pembelajaran yang teacher oriented menjadi student oriented. Salah satu kecakapan hidup (life skills) yang perlu dikembangkan selama proses pembelajaran adalah keterampilan berfikir. Keterampilan berfikir setiap orang akan terus berkembang dan dapat dipelajari dan karena rasa ingin tahu manusia juga selalu berkembang. Secara umum, terdapat empat tingkat berfikir manusia, yaitu: (1) Menghafal (recall thinking), merupakan tingkat berfikir lebih rendah atas keterampilan hampir otomatis atau refleksi. (2) Dasar (basic thinking), merupakan keterampilan dasar yang meliputi memahami konsep-konsep seperti penjumlahan,perkalian dan sebagainya termasuk aplikasinya dalam soal-soal. (3) Berfikir kritis (crtitical thinking), yaitu berfikir yang menghubungan dan mengevaluasi hal yang tekait. (4) Berpikir kreatif (creative thingking), merupakan kegiatan menyatukan ide, mencipta ide baru, dan mampu menentukan keefektifannya. (Salmon, 2012: 4)

Tingkat kemampuan berfikir dibedakan dengan mengelompokkan berdasarkan dimensi pengetahuan dan proses. Dimensi pengetahuan mencakup pengetahuan faktual, konseptual, prosedural dan pengetahuan metakognitif. Proses pengelompokkan ini dikenal dengan taksonomi Bloom. Dari keenam proses kognitif dalam taksonomi Bloom, tingkat analisis, evaluasi dan menciptakan merupakan tingkat berfikir yang lebih tinggi dibandingkan dengan tiga proses lainnya. Kemampuan berfikir tingkat tinggi (high order thinking skills)termasuk di dalamnya yaitu berfikir kritis, logis, kreatif, reflektif dan metakognitif. (FJ King, Ludwilca, Faranak Rohani). Paul dan Elder (2006) juga mengemukakan bahwa berfikir kritis menunjukkan beberapa karakter, yaitu: (1) Skeptik (skeptical), (2) Aktif, tidak pasif. Selalu bertanya, menganalisis dan mampu mengkomunikasikan argumen, (3) Tidak egois, terbuka terhadap ide dan hal-hal baru serta memiliki keinginan untuk saling adu argumen. Bloom

Berpikir kreatif merupakan cara berpikir yang menghasilkan sesuatu yang baru dalam bentuk konsep, penemuan, atau karya seni. Salah satu cara mengembangkan dan menguatkan kamampuan untuk berpikir kreatif adalah percaya bahwa sesuatu itu dapat dilakukan. Coleman \& Hammen (1974) Dengan demikian akan muncul adanya suatu dorongan yang dapat menggerakkan pikiran untuk mencari dan melaksanakan sesuatu yang diinginkan.

Ciri-ciri orang yang berpikir kreatif antara lain memiliki ide atau gagasangagasan baru, berani tampil beda atau melawan arus, memunculkan pemikiran yang tidak atau belum popular, optimistik, tidak takut untuk mencoba, tidak takut gagal, dan berani menanggung resiko. Dalam proses belajar, kelebihan model discovery learning dapat mendorong keterlibatan aktif siswa. Kelebihan discovery learning tersebut sesuai dengan pendekatan pembelajaran yang disarankan dalam Kurikulum 2013 yaitu pendekatan pembelajaran berdasarkan pengamatan, pertanyaan, pengumpulan data, penalaran, dan penyajian hasilnya melalui pemanfaatan berbagai sumber belajar. (Kemendikbud, 2013). Kelebihan 
discovery learning adalah (1) Membantu siswa untuk memperbaiki dan meningkatkan keterampilan-keterampilan dan proses-proses kognitif. Usaha penemuan merupakan kunci dalam proses ini, seseorang tergantung bagaimana cara belajarnya. (2) Metode ini memungkinkan siswa berkembang dengan cepat dan sesuai dengan kecepatannya sendiri. (3) Meningkatkan tingkat penghargaan pada siswa, karena unsur berdiskusi. (4) Menimbulkan rasa senang pada siswa, karena tumbuhnya rasa menyelidiki dan berhasil. (5) Membantu siswa menghilangkan skeptisme (keragu-raguan) karena mengarah pada kebenaran yang final dan tertentu atau pasti.

Beberapa kelebihan model discovery learning yakni (1) membantu siswa untuk memperbaiki dan meningkatkan keterampilan-keterampilan dan prosesproses kognitif, (2) pengetahuan yang diperoleh melalui model ini sangat pribadi dan ampuh karena menguatkan pengertian, ingatan, dan transfer, (3) dapat meningkatkan kemampuan siswa untuk memecahkan masalah, (4) membantu siswa memperkuat konsep dirinya, karena memperoleh kepercayaan bekerja sama dengan yang lain, (5) mendorong keterlibatan keaktifan siswa,(6) mendorong siswa berpikir intuisi dan merumuskan hipotesis sendiri, (7) melatih siswa belajar mandiri, (8) Siswa aktif dalam kegiatan belajar mengajar, karena ia berpikir dan menggunakan kemampuan untuk menemukan hasil akhir. Hosnan (2014: 287-288)

Kelebihan model discovery learning menimbulkan rasa senang pada siswa, karena tumbuhnya rasa menyelidiki dan berhasil, siswa akan mengerti konsep dasar dan ide-ide lebih baik, mendorong siswa berpikir dan bekerja atas inisiatif sendiri dan siswa dapat belajar dengan memanfaatkan berbagai jenis sumber belajar. Selain itu model ini juga dapat melatih keterampilan kognitif siswa untuk menemukan dan memecahkan masalah tanpa pertolongan orang lain.

Sementara itu kekurangannya adalah (1) metode ini menimbulkan asumsi bahwa ada kesiapan pikiran untuk belajar. Bagi siswa yang kurang pandai, akan mengalami kesulitan abstrak atau berfikir atau mengungkapkan hubungan antara konsep-konsep, yang tertulis atau lisan, sehingga pada gilirannya akan menimbulkan frustasi, (2) metode ini tidak efisien untuk mengajar jumlah siswa yang banyak, karena membutuhkan waktu yang lama untuk membantu mereka menemukan teori atau pemecahan masalah lainnya, (3) harapan-harapan yang terkandung dalam metode ini dapat buyar berhadapan dengan siswa dan guru yang telah terbiasa dengan cara-cara belajar yang lama, (4) pengajaran discovery lebih cocok untuk mengembangkan pemahaman, sedangkan aspek konsep, keterampilan dan emosi secara keseluruhan kurang mendapat perhatian, (5) tidak menyediakan kesempatan-kesempatan untuk berpikir yang akan ditemukan oleh siswa karena telah dipilih terlebih dahulu oleh guru. (Jurnal Pendidikan Universitas Garut Muhammad Vol. 09; No. 01; 2016; 9-22)

Dengan demikian model discovery learning dapat melatih siswa belajar secara mandiri melatih kemampuan bernalar siswa, serta melibatkan siswa secara aktif dalam kegiatan pembelajaran untuk menemukan sendiri dan memecahkan masalah tanpa bantuan orang lain. Selain itu juga perlu diketahui bahwa model discovery learning akan menyita banyak waktu karena mengubah cara belajar yang biasa digunakan, namun kekurangan tersebut dapat diminimalisir dengan merencanakan kegiatan pembelajaran secara terstruktur, memfasilitasi siswa dalam kegiatan penemuan serta mengonstruksi pengetahuan awal siswa agar pembelajaran dapat berjalan optimal.

Dalam penyusunan buku ajar perlu diperhatikan tahapan discovery learning, 
yaitu (1) stimulation (stimulasi/pemberian rangsang). Pada tahap ini siswa dihadapkan pada sesuatu yang menimbulkan kebingungan, kemudian dilanjutkan untuk tidak memberi generalisasi, agar timbul keinginan untuk menyelidiki sendiri. Guru dapat memulai dengan mengajukan pertanyaan, anjuran membaca buku, dan belajar lainnya yang mengarah pada persiapan pemecahan masalah. (2) problem statemen (pernyataan/identifikasi masalah), yaitu guru memberikan kesempatan kepada siswa untuk mengidentifikasi masalahmasalah yang relevan dengan bahan pelajaran, kemudian salah satunya dipilih dan dirumuskan dalam bentuk hipotesis, (3) data collection (pengumpulan data). Pada tahap ini siswa diberi kesempatan untuk mengumpulkan berbagai informasi yang relevan, membaca literatur, mengamati objek, wawancara, melakukan uji coba sendiri untuk menjawab pertanyaan atau membuktikan benar tidaknya hipotesis, (4) Data processing (pengolahan data), yaitu pengolahan data merupakan kegiatan mengolah data dan informasi yang telah diperoleh siswa melalui wawancara, observasi dan sebagainya. Tahap ini berfungsi sebagai pembentukan konsep dan generalisasi, sehingga siswa akan mendapatkan pengetahuan baru dari alternatif jawaban yang perlu mendapat pembuktian secara logis, (5) verification (pembuktian). Pada tahap ini siswa melalakukan pemeriksaan secara cermat untuk membuktikan benar atau tidaknya hipotesis yang ditetapkan tadi dengan temuan alternatif dan dihubungkan dengan hasil pengolahan data, (6) generalization (menarik kesimpulan). Tahap generalisasi/menarik kesimpulan adalah proses menarik sebuah kesimpulan yang dapat dijadikan prinsip umum dan berlaku untuk semua kejadian atau masalah yang sama, dengan memperhatikan hasil verifikasi.

Buku ajar dengan model discovery learning memiliki spesifikasi sebagai buku ajar dengan model pengajaran yang menekankan pentingnya membantu siswa untuk memahami struktur atau ide-ide kunci suatu disiplin ilmu, kebutuhan akan keterlibatan aktif siswa dalam proses belajar dan berorientasi pada proses. Siswa menemukan dan memecahkan sendiri masalah dalam pembelajaran melalui bantuan buku ajar dengan pendekatan saintifk. Siswa dituntut untuk menemukan sendiri melalui kegiatan saintifik yang dimulai dari mengamati, menanya, mengumpulkan informasi, menalar serta mengkomunikasikan yang mana siswa dituntut untuk berfikir kritis dalam menmukan pelajaran melalui langkah saintifk tersebut baik itu secara konseptual, maupun fakta dan nilai-nilai

\section{METODE PENELITIAN}

Metode penelitian yang digunakan adalah metode Research and Development, yaitu penelitian yang bertujuan untuk menghasilkan produk tertentu, dan menguji keefektifan produk tersebut. Produk yang dihasilkan yaitu Buku Ajar untuk pembelajaran Pendidikan Agama Islam dan Budi Pekerti kelas Sekolah Dasar. Prosedur pengembangan yang digunakan dalam penelitian ini adalah model pengembangan 4-D. Model pengembangan 4-D tediri atas empat tahap pengembangan, yaitu define, design, develop, dan disseminate. (Trianto, 2009: 189).

Pada penelitian pengembangan Buku Ajar dengan model discovery learning ini, dikembangkan sampai pada tahap tahap validasi dan praktikalisasi. Tahapan pengembangan yang dilakukan adalah (1) Tahap define (tahap pendefenisian). Tahap ini dilakukan untuk mengetahui permasalahan yang dihadapi oleh guru dan siswa yang berkaitan dengan keadaan bahan ajar yang telah ada. Tahapan ini juga dilakukan untuk mengetahui tingkat akurasi buku ajar yang ada dengan melakukan pengukuran dan penilaian dengan menggunakan instrumen penilaian. Tahap ini dilakukan untuk mengetahui 
keadaan di lapangan, tahap ini bisa disebut tahap analisis kebutuhan. Pada tahap ini dilakukan (a) observasi dan wawancara dengan guru bidang studi Pendidikan Agama Islam di SDN Kota Batusangkar. Observasi dan wawancara dengan guru bidang studi bertujuan untuk mengetahui masalah, hambatan serta fenomena apa saja yang dihadapi di lapangan sehubungan dengan mata pelajaran Pendidikan Agama Islam. Masalah, hambatan atau fenomena dapat berasal dari guru maupun dari siswa, (b) menganalisis silabus dan RPP PAI dan Budi Pekerti kelas V SD, hal ini bertujuan untuk mengetahui apakah materi yang diajarkan sudah sesuai dengan Kompetensi Inti dan Kompetensi Dasar mata pelajaran Pendidikan Agama Islam, (c) menganalisis buku teks Pendidikan Agama Islam kelas V.

Sebelum merancang buku ajar pembelajaran Pendidikan Agama Islam dengan model discovery learning, buku teks pendidikan agama Islam sudah ditelaah terlebih dahulu. Hal ini bertujuan untuk melihat isi buku, cara penyajian serta contoh dan tugas yang diberikan apakah sudah sesuai dengan silabus mata pelajaran Pendidikaan Agama Islam. Hal dilakukan untuk itu adalah mereview literatur tentang Buku Ajar. Hal ini bertujuan untuk mengetahui format penulisan buku ajar, agar buku ajar yang akan dikembangkan dapat dirancang dengan baik dan semenarik mungkin. Buku ajar merupakan bahan ajar mandiri yang dapat dipelajari siswa tanpa bantuan guru dan arahan tutor. Oleh karena itu, buku ajar harus memuat contoh soal yang dapat dipahami oleh siswa. (2) Tahap design (tahap perancangan). Tahap design bertujuan untuk menyiapkan prototype perangkat pembelajaran. Tahap ini dirancang buku ajar Pendidikan Agama Islam dengan model discovery learning kelas V SD, dalam buku ajar terdapat ringkasan materi beserta lembaran kerja siswa yang berisikan soal-soal yang akan dikerjakan oleh siswa, (3) Tahap develop (tahap pengembangan). Tahap ini peneliti membatasi sampai tahap validasi. Validasi dilakukan dalam bentuk tertulis dan diskusi dengan pakar sampai pakar berpendapat bahwa buku ajar pembelajaran Pendidikan Agama Islam dengan model discovery learning yang dikembangkan telah valid. Ada dua macam validasi yang digunakan pada buku ajar pembelajaran Pendidikan Agama Islam berbasis kontruktivisme yaitu validasi isi, untuk mengetahui apakah buku ajar pembelajaran Pendidikan Agama Islam dengan model discovery learning yang telah dirancang sesuai dengan silabus mata pelajaran PAI kelas V SD. Validasi konstruk, yaitu kesesuaian komponenkomponen buku ajar pembelajaran Pendidikan Agama Islam dengan model discovery learning dengan indikator yang telah ditetapkan.

Teknik pengumpulan data yang digunakan dalam penelitian ini adalah (1) instrumen penilaian dalam bentuk format analisis buku siswa untuk mengukur tingkat akurasi buku ajar yang telah ada, (2) wawancara dan observasi, dilakukan dengan guru bidang studi PAI dan Budi Pekerti bertujuan untuk mengetahui permasalahan yang dihadapi guru dalam penggunaan buku ajar yang telah ada, (3) lembar validasi.

Kegiatan validasi ini dilakukan dalam bentuk mengisi lembar validasi buku ajar pembelajaran Pendidikan Agama Islam dengan model discovery learning sampai produk dinyatakan valid. Instrumen yang digunakan dalam penelitian ini adalah format analisis buku siswa dan lembar validasi buku ajar. Format analisis buku siswa digunakan untuk mengetahui hasil analisis guru terhadap buku siswa pada mata pelajaran PAI dan Budi Pekerti Sekolah Dasar. Lembar validasi digunakan untuk mengetahui apakah buku ajar pembelajaran Pendidikan Agama Islam dengan model discovery learning dan 
instrumen yang telah dirancang valid atau tidak. Lembar validasi pada penelitian ini adalah lembar validasi buku ajar pembelajaran Pendidikan Agama Islam dengan model discovery learning.

Lembar validasi Buku ajar pembelajaran Pendidikan Agama Islam dengan model discovery learningberisi aspek-aspek yang telah dirumuskan. Masing-masing aspek dikembangkan menjadi beberapa pernyataan dandiisi validator.

Teknik analisis data yang dipakai dalam mengemukakan hasil penelitian adalah analisis validasi terhadap instrumen penelitian pada aspek validitas menggunakan teknik analisis antar rater. Teknik analisis antar rater adalah salah satu teknik analisis yang digunakan koefisien korelasi intrakelas (Intraclass Correlation Coefficient-ICC). Uji reliabilitas antar rater ICC digunakan 4 rater sehingga menggunakan koefisien korelasi antar kelas. ICC menunjukkan perbandingan antar variasi yang diakibatkan atribut yang diukur dengan variasi pengukuran secara keseluruhan.

Kualitas produk hasil pengembangan yang diharapkan dalam penelitian ini adalah produk yang valid. Produk yang valid adalah produk yang memenuhi aspek yang divalidasikan, yaitu meliputi aspek tujuan, rasionalitas, isi buku ajar, karakteristik buku ajar, bahasa dan tampilan.

\section{HASIL DAN PEMBAHASAN}

Tahap define (tahap pendefenisian)

Tahapan ini dilakukan untuk mengetahui tingkat akurasi buku ajar yang ada dengan melakukan pengukuran dan penilaian dengan menggunakan instrumen penilaian. Tahap ini dilakukan untuk mengetahui penilaian dan analisis guru mata pelajaran Pendidikan Agama Islam dan Budi Pekerti terhadap buku pegangan siswa, Tahap ini bisa disebut tahap analisis kebutuhan (define).
Hasil analisis terhadap tingkat akurasi buku ajar Pendidikan Agama Islam dan Budi Pekerti kelas 5 (lima) Sekolah Dasar dapat dilihat pada tabel berikut:

\begin{tabular}{|c|c|c|c|c|}
\hline \multirow[b]{2}{*}{$\begin{array}{l}\mathbf{N} \\
\mathbf{O}\end{array}$} & \multirow{2}{*}{$\begin{array}{l}\text { Aspek } \\
\text { yang } \\
\text { Dianalisis } \\
\end{array}$} & \multicolumn{3}{|c|}{ HASIL ANALISIS } \\
\hline & & $\begin{array}{l}\text { Tidak } \\
\text { terpenuhi }\end{array}$ & $\begin{array}{l}\text { Terpenuhi } \\
\text { sebagian }\end{array}$ & $\begin{array}{l}\text { Terpe } \\
\text { nuhi }\end{array}$ \\
\hline 1. & $\begin{array}{l}\text { Kesesuaian } \\
\text { dengan } \\
\text { Standar } \\
\text { Kompetensi } \\
\text { Lulusan }\end{array}$ & $0 \%$ & $37,5 \%$ & $62,5 \%$ \\
\hline 2. & $\begin{array}{l}\text { Kesesuaian } \\
\text { dengan } \\
\text { Kompetensi } \\
\text { Inti }\end{array}$ & $0 \%$ & $25 \%$ & $75 \%$ \\
\hline 3. & $\begin{array}{l}\text { Kesesuaian } \\
\text { dengan } \\
\text { Kompetensi } \\
\text { Dasar }\end{array}$ & $0 \%$ & $50 \%$ & $50 \%$ \\
\hline 4. & $\begin{array}{l}\text { Kesesuaian } \\
\text { materi } \\
\text { dengan } \\
\text { tema }\end{array}$ & $0 \%$ & $37,5 \%$ & $62,5 \%$ \\
\hline 5. & $\begin{array}{l}\text { Kecukupan } \\
\text { materi } \\
\text { ditinjau } \\
\text { dari: } \\
\text { a.cakupan } \\
\text { konsep/mat } \\
\text { eri esensial; } \\
\text { b.alokasi } \\
\text { waktu. }\end{array}$ & $\begin{array}{l}12,5 \% \\
50 \%\end{array}$ & $\begin{array}{l}87,5 \% \\
50 \%\end{array}$ & $\begin{array}{l}0 \% \\
0 \%\end{array}$ \\
\hline 6. & $\begin{array}{l}\text { Kedalaman } \\
\text { materi } \\
\text { pengayaan } \\
\text { ditinjau } \\
\text { dari: } \\
\text { a. Pola } \\
\quad \text { pikir } \\
\quad \text { keilmuan } \\
\quad \text {; dan } \\
\text { b. Karakter } \\
\quad \text { istik } \\
\quad \text { siswa }\end{array}$ & $25 \%$ & $75 \%$ & $0 \%$ \\
\hline 7. & $\begin{array}{l}\text { Keterpadua } \\
\mathrm{n} \text { berbagai } \\
\text { kompetensi } \\
\text { /aspek }\end{array}$ & $25 \%$ & $75 \%$ & $0 \%$ \\
\hline 8. & $\begin{array}{l}\text { Penerapan } \\
\text { Pendekatan } \\
\text { Scientific }\end{array}$ & $25 \%$ & $75 \%$ & $0 \%$ \\
\hline 9. & $\begin{array}{l}\text { Penilaian } \\
\text { Autentik } \\
\text { yang } \\
\text { Tersedia } \\
\text { dalam } \\
\text { Buku Siswa }\end{array}$ & $87,5 \%$ & $12,5 \%$ & $0 \%$ \\
\hline 10. & $\begin{array}{l}\text { Kolom } \\
\text { interaksi } \\
\text { antara guru } \\
\text { dengan } \\
\text { orangtua }\end{array}$ & $0 \%$ & $100 \%$ & $0 \%$ \\
\hline
\end{tabular}

Guru Pendidikan Agama Islam dan Budi Pekerti Sekolah Dasar di Kota Batusangkar mengungkapkan bahwa Buku Ajar Siswa baru mampu memenuhi 62,5 \% Standar Kompetensi Lulusan siswa kelas lima Sekolah Dasar. Sebanyak 37,5 \% 
lainnya guru menyatakan bahwa buku ajar yang ada hanya memenuhi sebagian dari Standar Kompetensi Lulusan. Menurut guru, perlu disediakan buku ajar yang benar-benar mampu memenuhi keseluruhan Standar Kompetensi Lulusan pada mata pelajaran PAI dan Budi Pekerti.

Dalam hal kesesuaian dengan Kompetensi Inti, sebanyak $75 \%$ guru menyatakan bahwa buku ajar yang tersedia sudah memenuhi Kompenesi Inti. Sedangkan $25 \%$ lainnya menyatakan baru sebagian terpenuhi dari kompetensi inti yang ada. Oleh karena itu, guru berharap ada buku ajar yang mampu memenuhi keseluruhan dari Kompetensi Inti yang ada pada mata pelajaran PAI dan Budi Pekerti.

Menurut guru, buku ajar yang ada baru memenuhi sebagian $(50 \%)$ dari kompetensi dasar yang ada. Sebagian guru lainnya $(50 \%)$ menyatakan bahwa kompetensi dasar yang ada tidak terpenuhi. Oleh karena itu, guru berharap ada buku ajar yang mampu mengakomodir seluruh kompenesi dasar yang ada secara lengkap dan memadai.

Kesesuaian uraian materi ajar dengan tema pada setiap pembelajaran menurut guru baru memenuhi 62,5\%, sedangkan $37.5 \%$ lainnya guru menyatakan bahwa hanya sebagian yang terpenuhi. Dengan demikian guru berharap, ada buku ajar yang mampu memenuhi keseluruhan tema yang ada.

Kecukupan materi ditinjau dari cakupan konsep/materi esensial menurut $87,5 \%$ guru baru sebagian yang memenuhi. Sedangkan 12,5\% lainnya guru menyatakan bahwa cakupan konsep/materi esensial tidak memenuhi. Sedangkan mengenai alokasi waktu yang tersedia, menurut sebagian guru $(50 \%)$ baru sebagian yang mencukupi, sedangkan sebagian lainnya $(50 \%)$ guru menyatakan tidak memenuhi. Oleh karena itu, menurut guru perlu disediakan buku ajar yang relevan dengan kesesuaian alokasi waktu yang tersedia.

Dari segi kedalaman materi pengayaan ditinjau dari pola pikir keilmuan, sebanyak $75 \%$ guru menyatakan hanya sebagian yang terpenuhi, sedangkan $25 \%$ lainnya guru menyatakan tidak terpenuhi pengayaan materi ditinjau dari segi pola pikir keilmuan. Sebanyak $75 \%$ guru juga menyatakan bahwa buku ajar yang ada hanya sebagian yang mampu memenuhi pengayaan materi ditinjau dari segi karakteristik siswa. Sedangkan 25\% lainnya guru menyatakan bahwa pengayaan materi dari segi karakateristik siswa tidak terpenuhi. Dengan demikian, guru berharap dapat disediakan buku ajar yang mampu memenuhi pengayaan materi secara baik dan lengkap dari pola pikir keilmuan dan karakteristik siswa.

$$
\text { Dari keterpaduan berbagai }
$$

kompetensi/aspek, sebanyak $75 \%$ guru menyatakan bahwa buku ajar yang tersedia hanya memenuhi sebagian. Sedangkan $25 \%$ guru lainnya menyatakan bahwa buku ajar yang ada tidak memenuhi keterpaduan berbagai kompetensi/aspek yang ada. Dengan demikian, guru berharap dapat disediakan buku ajar yang mampu memenuhi keterpaduan berbagai kompetensi/aspek yang harus dimiliki oleh anak didik.

Sebanyak $75 \%$ guru menyatakan bahwa buku ajar yang ada hanya sebagian memenuhi pendekatan saintifik. Sedangkan 25\% lainnya guru menyatakan bahwa buku ajar yang ada tidak memenuhi pendekatan saintifik. Maka guru sangat mengharapkan adanya buku ajar yang mampu menyediakan pendekatan saintifik secara lengkap.

Sebanyak $87,5 \%$ guru menyatakan bahwa buku siswa yang ada tidak memenuhi penilaian autentik yang tersedia. Sebanyak $12,5 \%$ lainnya menyatakan hanya sebagian yang terpenuhi. Dengan demikian, diperlukan buku ajar yang mammpu memenuhi penilaian autentik secara baik.

$$
\text { Keseluruhan guru }
$$
menyatakan bahwa buku siswa yang ada sekarang baru memenuhi sebagian dari kolom interaksi guru dan orangtua. Oleh karena itu,dibutuhkan buku ajar yang 
mampu memaksimalkan terjadinya interaksi antara guru dan orangtua dalam membimbing dan mengawasi belajar anak.

Hasil analisis buku siswa di atas menunjukkan bahwa kondisi buku ajar yang ada belum mampu memenuhi kebutuhan guru dan siswa secara maksimal dalam pembelajaran Pendidikan Agama Islam dan Budi Pekerti. Pada beberapa bagian buku ajar, perlu ada penyempurnaan. Terutama hal berkaitan dengan pendekatan pembelajaran dan penilaian. Pendekatan saintifik yang diterapkan belum memaksimalkan semua langkah yang ada. Dari segi kecukupan materi yang ditinjau dari cakupan konsep/materi esensial dan alokasi waktu yang tersedia perlu dilengkapi dengan mempertimbangan ketersediaan waktu yang ada. Demikian juga dari segi kedalaman materi pengayaan yang ditinjau dari pola pikir keilmuan dan karakteristik siswa perlu dilengkapi lagi.

Dengan demikian, maka dibutuhkan suatu buku ajar yang lengkap dan mudah dipahami oleh siswa. Buku ajar seharusnya juga mampu memenuhi kebutuhan guru dan siswa. Hal ini menjadi alasan yang kuat terhadap perlunya pengembangan buku ajar berbasis discovery dan saintifik sebagai pegangan bagi siswa pada mata pelajaran PAI dan Budi Pekerti.

Tahap design (tahap perancangan)

Buku ajar Pendidikan Agama Islam dan Budi Pekerti kelas lima Sekolah Dasar dirancang untuk memenuhi kebutuhan siswa terhadap buku ajar yang lengkap, menarik dan mudah dipahami. Buku ajar pembelajaran Pendidikan Agama Islam dengan model discovery learning yang telah dirancang dapat dikemukakan dengan bagian-bagian (1) Cover. Cover dibuat dengan menggunakan jenis dan ukuran tulisan yang jelas serta disain warna yang menarik. Cover ini menimbulkan kesan yang menarik dan mudah diingat oleh siswa serta menggambarkan basis utama buku ajar dan identitas mata pelajaran dan siswa. (2)
Kompetensi dasar. Kompenetesi Dasar yang dicantumkan padea buku ajar disesuaikan dengan yang terdapat pada Standar Kompetensi Lulusan pada mata pelajaran Pendidikan Agama Islam dan Budi Pekerti kelas lima Sekolah Dasar. Pernyataan tentang Kompetensi Dasar dibuat dengan jelas dan menggunakan jenis huruf yang menarik, sehingga siswa mudah membaca dan mengingatnya. (3) Materi Ajar. Materi ajar adalah uraian materi ajar yang sesuai dengan kompetensi dasar dan tujuan pembelajaran. Uraian materi ajar disusun dengan memperkuat pengayaan materi ajar dengan memperhatikan karateristik siswa kelas lima Sekolah Dasar.Uraian materi ajar dibuat dengan sajian yang menarik, dengan tujuan untuk memotivasi siswa dalam pembelajaran. Materi ajar dirancang dengan memperhatikan langkah-langkah discovery dan saintifik, sehingga setiap langkah tersebut akan mampu memudahkan siswa dalam memahami materi ajar. Di samping itu, materi ajar juga disusun dengan mempertimbangkan alokasi waktu yang tersedia, sehingga guru dan siswa dapat belajar sesuai dengan alokasi waktu yang tersedia dengan muatan materi ajar yang relevan dengan tujuan pembelajaran yang sudah ditetapkan. Berikut ini adalah salah satu bagian buku ajar discovery yang memuat tentang materi ajar. (4) Kegiatan siswa. Pada buku ajar Pendidikan Agama Islam berbasis discovery kegiatan siswa dirumuskan dengan jelas dengan mempertimbangkan karakteristik siswa yang sedang dalam masa pertumbuhan dan perkembangan. Kegiatan siswa dirumuskan berdasarkan langkah-langkah discovery learning, sehingga kegiatan pembelajaran yang berlangsung menekankan kepada aktifitas siswa dalam pembelajaran. (5) Evaluasi. Evaluasi bertujuan untuk melakukan pengukuran terhadap kemampuan siswa setelah mengikuti kegiatan pembelajaran dengan menggunakan buku ajar berbasis discovery learning. Evaluasi dilakukan dengan 
penilaian proses dan penilaian autentik. Instrumen evaluasi disusun berdasarkan Kompetensi Dasar dan tujuan pembelajaran yang relevan. Buku ajar yang dirancang akan memudahkan siswa dalam menjawab soal-soal latihan dan evaluasi, sehingga akan dapat membantu siswa dalam mencapai tujuan pembelajaran. (6) Lembar jawaban. Pada buku ajar yang dirancang disedian halaman khusus yang dapat dimanfaatkan oleh siswa sebagai lembar jawaban, yaitu lembaran yang disediakan untuk menjawab soal-soal evaluasi. Hal ini akan memudahkan siswa untuk menjawab soalsoal latihan dan evaluasi dan juga memudahkan guru untuk memberikan penilaian. (7) Lembar komentar orang tua. Pada buku ajar Pendidikan Agama Islam dan Budi Pekerti berbasis discovery juga disediakan lembar komentar orangtua. Lembar komentar orangtua, yaitu lembaran yang disediakan untuk orangtua agar dapat memberikan komentar terhadap kegiatan belajar siswa serta saran-saran yang perlu disampaikan terkait dengan kegiatan pembelajaran. Lembaran ini memungkinkan terjadinya interaksi yang positif antara guru dan orangtua dalam memberikan bimbingan dan pengawasan terhadap kegiatan belajar siswa. Lembaran ini juga dapat dimanfaatkan oleh guru sebagai lembar refleksi untuk melakukan perbaikan-perbaikan yang diperlukan dalam proses pembelajaran, yaitu dengan memperhatikan catatan dan saran yang diberikan oleh orangtua pada lembar ini.

Tahap develop (tahap pengembangan)

$$
\text { Tahap }
$$$$
\text { develop }
$$

(tahap

pengembangan), yaitu tahapan pengembangan produk yang dilakukan dengan prosedur penilaian (assessment) oleh tim validator (pakar) terhadap buku ajar dengan model discovery lerning untuk kelas lima Sekolah Dasar. Tahap pengembangan dilakukan dengan berdiskusi dengan pakar dan penilaian terhadap produk yang dirancang. Tim pakar atau validator berasal dari kalangan akademisi dan praktisi, sehingga dianggap layak dan tepat untuk memberikan penilaian dan masukan untuk penyempurnaan buku ajar Pendidikan Agama Islam dengan discovery learning.

Hasil validasi buku ajar dengan model discovery lerning di kelas lima Sekolah Dasar dapat dilihat pada tabel berikut:

\begin{tabular}{|c|c|c|c|c|c|c|}
\hline \multirow{2}{*}{ No } & \multirow{2}{*}{$\begin{array}{l}\text { Aspek } \\
\text { yang } \\
\text { Divalidasi }\end{array}$} & \multicolumn{3}{|c|}{ Validator } & \multirow{2}{*}{$\begin{array}{l}\text { INDEKS } \\
\text { ICC }\end{array}$} & \multirow[t]{2}{*}{ Ket. } \\
\hline & & 1 & 2 & 3 & & \\
\hline 1. & $\begin{array}{l}\text { Aspek } \\
\text { kelayakan } \\
\text { isi }\end{array}$ & 28 & 30 & 28 & 0,97 & valid \\
\hline 2. & $\begin{array}{l}\text { Aspek } \\
\text { kelayakan } \\
\text { penyajian }\end{array}$ & 56 & 59 & 53 & 0,97 & valid \\
\hline 3. & $\begin{array}{l}\text { Aspek } \\
\text { penilaian } \\
\text { saintifik }\end{array}$ & 55 & 66 & 56 & 0,96 & valid \\
\hline 4. & $\begin{array}{l}\text { Aspek } \\
\text { kelayakan } \\
\text { bahasa }\end{array}$ & 11 & 9 & 9 & 0,98 & valid \\
\hline \multicolumn{5}{|c|}{ Jumlah } & 0,97 & valid \\
\hline
\end{tabular}

Dari segi kelayakan isi, buku ajar dengan model discovery sudah dinyatakan valid oleh validator. Indikator yang dinilai oleh validator pada aspek kelayakan isi mencakup materi yang disajikan dalam buku ajar dengan model discovery learning sudah mencakup materi yang terkandung dalam $\mathrm{KD}$ dan Indikator pencapaian kompetensi.

Materi yang disajikan pada buku ajar dengan model discovery learning juga dinyatakan sudah mencerminkan jabaran yang mendukung Indikator pencapaian kompetensi. Pada bagian materi yang disajikan pada buku ajar dengan model discovery learning pada kelas $\mathrm{V}$ sesuai dengan tingkat pendidikan Sekolah Dasar dinyatakan sudah sesuai dengan kompetensi dasar

Menurut validator konsep dan defenisi yang disajikan dalam buku ajar dengan model discovery learning jelas dan tidak menimbulkan banyak pertanyaan dan sesuai dengan konsep dan defenisi yang berlaku. Begitu juga dengan fakta dan data yang disajikan dalam buku ajar dengan model discovery learning sudah sesuai dengan kenyataan dan efisien untuk meningkatkan pemahaman siswa. Contohcontoh yang disajikan dalam buku ajar 
dengan model discovery learning juga sudah sesuai dengan kenyataan dan efisien untuk meningkatkan pemahaman peserta didik. Latihan dan contoh-contoh yang disajikan dalam buku ajar dengan model discovery learning mampu mendorong peserta didik untuk mengetahui materi lebih jauh.

Penilaian dari tim validator menunjukkan bahwa buku ajar dengan model discovery learning akan membantu siswa dalam menemukan konsep dan prinsip-prinsip melalui proses mentalnya sendiri melalui pengamatan, menggolongkan, membuat dugaan, menjelaskan, menarik kesimpulan dan sebagiannya untuk menemukan beberapa konsep atau prinsip

Pembelajaran dalam buku ajar dengan discovery learning juga akan mampu mendorong siswa lebih berfikir kritis dan aktif dalam pembelajaran dalam pengembangan pengatahuan, karena materi dalam buku ajar dengan model discovery learning berbasis saintifik mampu meningkatkan kemampuan inquiry serta mengembangkan pengetahuan dan keterampilan peserta didik

Materi dalam buku dengan model discovery learning mampu merangsang peserta didik dalam memecahkan masalah terkait pertanyaan-pertanyaan atau menemukan masalah dengan membaca sendiri (stimulation), karena materi ajar dalam buku ajar dengan model discovery learning memotivasi peserta didik untuk mampu mengidentifikasi masalah yang relevan dengan pelajaran dan merumuskan hipotesi (data collection). Materi dalam buku ajar dengan model discovery learning mampu nmenggiring peserta didik untuk mengumpulkan data melalui observasi atau wawancara dan sebagainya untuk mendapatkan pengetahuan baru (data processing), serta membimbing peserta didik melakukan pemeriksaan secara cermat terkait konsep yang ditemukan yang dihubungkan dengan pengolahan data (verification)
Dalam buku ajar dengan model discovery learning peserta didik dibimbing untuk mampu menarik kesimpulan yang terkait pemecahan masalah materi yang dipelajari (generalization), karena masingmasing materi memiliki keterkaitan antara materi yang diajarkan dengan situasi dunia nyata peserta didik baik secara konseptual maupun faktual.

Proses pembelajaran dengan menggunakan buku ajar model discovery learning akan mampu mendorong siswa untuk membuat hubungan anatara pengetahuan yang dimiliki peserta didik dengan penerapannya dalam kehidupan sehari-hari, karena sifat materi ajar dalam buku ajar dengan model discovery learning bersifat konseptual, faktual, dan memuat langkah-langkah saintifik.

Materi dalam buku ajar dengan model discovery learning merangsang siswa untuk menemukan pengetahuan sendiri melalui hasil pengamatan dengan melihat, membaca ataupun mendengar (mengamati). Begitu juga dengan materi dalam buku ajar dengan model discovery learning akan mampu merangsang siswa untuk mengajukan pertanyaan terkait hasil pengamatan baik pertanyaan yang bersifat kongkrit maupun abstrak (menanya)

Pertanyaan yang terdapat dalam buku ajar dengan model discovery learning dapat mendorong, membimbing dan mengukur kemampuan berfikir siswa dalam mengumpulakn sejumlah informasi dari berbagai sumber dari hasil pengamatan pada materi (mengumpulkan data). Pada buku ajar ini terdapat tugas kelompok dan materi merangsang siswa untuk berdiskusi secara berkelompok untuik menemukan informasi dan dapat mengambil kesimpulan dari informasi yang ditemukan (mengasosiasi). Buku ajar ini juga memungkinkan siswa untuk menyampaikan ide dan pemecahan masalah mulai dari kegiatan mengamati sampai mengasosiasi dari materi yang telah dipelajari (mengkomunikasikan), karena pada buku ajar terdapat rangkuman materi yang telah dipelajari (refleksi)〉 
Buku ajar model discovery learning pada mata pelajaran Pendidikan Agama Islam dan Budi Pekerti kelas lima Sekolah Dasar sudah dinyatakan valid. Produk ini disempurnakan berdasarkan masukan dan catatan yang diberikan oleh validator, sehingga dapat dikatakan layak untuk digunakan pada pembelajaran Pendidikan Agama Islam dan Budi Pekerti kelas lima Sekolah Dasar. Buku ajar ini juga akan dapat membantu guru dan siswa dalam proses pembelajaran untuk mencapai tujuan pembelajaran yang sudah ditetapkan.

\section{PEMBAHASAN}

Hasil analisis buku siswa menunjukkan bahwa kondisi buku ajar yang ada belum mampu memenuhi kebutuhan guru dan siswa secara maksimal dalam pembelajaran Pendidikan Agama Islam dan Budi Pekerti. Perlu dilakukan penyempurnaan pada beberapa bagian buku ajar, terutama hal berkaitan dengan pendekatan pembelajaran dan penilaian. Pendekatan discovery learning perlu diterapkan dengan memaksimalkan semua langkah yang ada. Dengan discovery learning materi ajar dapat disajikan secara lengkap dan mampu membawa siswa terlibat secara aktif untuk menemukan sendiri suatu konsep ataupun prinsip yang belum diketahuinya.

Penilaian dari tim validator menunjukkan bahwa buku ajar dengan model discovery learning berbasis saintifik akan membantu siswa dalam menemukan konsep dan prinsip-prinsip melalui proses mentalnya sendiri melalui pengamatan, menggolongkan, membuat dugaan, menjelaskan, menarik kesimpulan dan sebagiannya untuk menemukan beberapa konsep atau prinsip. Buku ajar dengan discovery learning mampu mendorong siswa lebih berfikir kritis dan aktif dalam pembelajaran dalam pengembangan pengatahuan, karena materi dalam buku ajar mampu meningkatkan kemampuan inquiri serta mengembangkan pengetahuan dan keterampilan peserta didik
Begitu juga pada uraian materi ajar berbasis discovery learning mampu merangsang peserta didik dalam memecahkan masalah terkait pertanyaanpertanyaan atau menemukan masalah dengan membaca sendiri (stimulation), karena materi ajar yang dipaparkan mampu memotivasi peserta didik untuk mampu mengidentifikasi masalah yang relevan dengan pelajaran dan merumuskan hipotesis (data collection), mengumpulkan data melalui observasi atau wawancara dan sebagainya untuk mendapatkan pengetahuan baru (data processing), membimbing peserta didik melakukan pemeriksaan secara cermat terkait konsep yang ditemukan yang dihubungkan dengan pengolahan data (verification, dan menarik kesimpulan yang terkait pemecahan masalah materi yang dipelajari (generalization), karena masing-masing materi memiliki keterkaitan antara materi yang diajarkan dengan situasi dunia nyata peserta didik baik secara konseptual maupun faktual.

Proses pembelajaran dengan menggunakan buku ajar model discovery learning mampu mendorong siswa untuk membuat hubungan anatara pengetahuan yang dimiliki peserta didik dengan penerapannya dalam kehidupan seharihari, karena sifat materi ajar dalam buku ajar dengan model discovery learning berbasis saintifik bersifat konseptual, faktual, dan memuat langkah-langkah saintifik.

Buku ajar ini juga memungkan siswa untuk menyampaikan ide dan pemecahan masalah mulai dari kegiatan mengamati sampai mengasosiasi dari materi yang telah dipelajari (mengkomunikasikan), karena pada buku ajar terdapat rangkuman materi yang telah dipelajari (refleksi)

Hasil validasi menunjukkan bahwa buku ajar berbasis discovery learning pada mata pelajaran Pendidikan Agama Islam dan Budi Pekerti kelas lima Sekolah Dasar dinyatakan valid. Produk ini sudah disempurnakan berdasarkan masukan dan catatan yang diberikan oleh validator, 
sehingga dapat dikatakan layak untuk digunakan pada pembelajaran Pendidikan Agama Islam dan Budi Pekerti kelas lima Sekolah Dasar. Buku ajar ini juga akan dapat membantu guru dan siswa dalam proses pembelajaran untuk mencapai tujuan pembelajaran yang sudah ditetapkan.

Buku ajar berbasis discovery learning mampu memenuhi kebutuhan guru dan siswa. Hal ini menjadi alasan yang kuat terhadap perlunya perlunya penggunaan buku ajar berbasis discovery learning sebagai pegangan bagi siswa pada mata pelajaran PAI dan Budi Pekerti Sekolah Dasar.

\section{KESIMPULAN}

Penelitian dan pengembangan yang telah dilakukan menghasilkan kesimpulan (1) Tingkat akurasi buku ajar Pendidikan Agama Islam dan Budi Pekerti kelas lima Sekolah Dasar masih rendah. Pada umumnya guru menyatakan bahwa buku ajar yang baru mampu memenuhi sebagian dari kompetensi dasar dan indikator bahan ajar dibutuhkan oleh siswa. Menurut guru PAI dan Budi Pekerti, buku ajar yang perlu disempurnakan dan diperjelas langkah-langkah kegiatan belajar siswa, sehingga dapat memudahkan siswa dalam belajar. (2) Berdasarkan penilaian validator deketahui bahwa produk pengembangan buku ajar model discovery learning pada mata pelajaran Pendidikan Agama Islam dan Budi Pekerti kelas lima Sekolah Dasar dinyatakan valid. Produk ini sudah disempurnakan berdasarkan masukan dan catatan yang diberikan oleh validator, sehingga dapat dikatakan layak untuk digunakan pada pembelajaran Pendidikan Agama Islam dan Budi Pekerti kelas lima Sekolah Dasar. Buku ajar ini juga akan dapat membantu guru dan siswa dalam proses pembelajaran untuk mencapai tujuan pembelajaran yang sudah ditetapkan.

\section{DAFTAR PUSTAKA}

Abdul Majid, 2014. Pembelajaran Tematik Terpadu, Bandung: PT. Remaja Rosdakarya.

Agus Susilo, Pengembangan Modul Berbasis Pembelajaran Saintifik Untuk Peningkatan Kemampuan Aplikatif Dan Mencipta Siswa Dalam Proses Pembelajaran Akuntansi 2015. http://dglib.uns.ac.id tesis agung trisno Pdf.

Asis Saefuddin \& Ika Berdiati, 2015. Pembelajaran Efektif, Bandung: PT. Remaja Rosdakarya.

Asep Harry Hermawan, dkk, Pembelajaran Terpadu di SD (Jakarta. Universitas Terbuka: 2009)

e-Journal Ellyza Sri Widyastuti, Penerapan Model Pembelajaran Discovery Learning Pada Materi Konsep Ilmu Ekonomi (Surabaya: Universitas Negeri Surabaya,)

e-Jurnal Pendidikan Universitas Garut Vol. 09; No. 01; 2016; 9-22 www.journal.uniga.ac.id

e- Journal Tina Wahyu Lestari, Pengaruh Model Pembelajaran Discovery Learning disertai Media Kartu, Masalah terhadap Kemampuan Berpikir Kritis Siswa dan Hasil Belajar Siswa dalam Pembelajaran IPA di SMPN 10 Jember 2016 (Kalimantan Universitas Jember (UNEJ))

$\begin{array}{crr}\text { Fadriati. Strategi } & \text { dan } & \text { Teknik } \\ \text { Pembelajaran } & \text { PAI. } & 2014, \\ \text { (Batusangkar: } & \text { STAIN } & \text { Batusangkar } \\ \text { Press) } & & \end{array}$

Nana Syaodih Sukmadinata, Metode Penelitian Pendidikan (Bandung: PT Remaja Rosdakarya, 2009) 
Sinar Grafika, Undang-Undang SISDIKNAS (Sistem Pendidikan Nasional) 2003, (Jakarta: Sinar Grafika, 2003

Rhendi Feri Andrian Umbaran, 2015. Pengembangan Modul berbasis pendekatan saintifik kompesensi dasar mendeskripsikan pengertian, pertemuan/rapat kelas XI APK 2 SMK Ngajuk. http:// ejournal.unesa.ac.idarticle1626555ar ticle.pdf.

Ridwan Abdullah Sani, 2014. Pembelajaran Saintifik Untuk Implementasi Kurikulum 2013, Jakarata: PT. Bumi Aksara.
Soekanto, Lembar Kerja Siwa, (Jakarta: Grasindo, 1998)

Sugiyono, Metode Penelitian Pendidikan (Pendekatan Kuantitatif, Kualitatif, dan $R$ \& D), (Bandung: Alfabeta, 2007)

Trianto, Mendesain Model Pembelajaran Inovatif-Progresif: Konsep, Landasan dan Implementasinya pada Kurikulum Tingkat Satuan Pendidikan (KTSP), (Jakarta: Kencana Prenada Media Group, 2009)

Wina Sanjaya, Kurikulum dan Pembelajaran, (Jakarta: Kencana Prenada Media Group, 2008) 